\title{
Polar Bear (Ursus maritimus) Denning in the Area of the Simpson Peninsula, Nunavut
}

\author{
FRANZ VAN DE VELDE, OMI, ${ }^{1}$ IAN STIRLING ${ }^{2,3}$ and EVAN RICHARDSON ${ }^{2}$
}

(Received 8 May 2002; accepted in revised form 16 October 2002)

\begin{abstract}
The locations of polar bear snow dens in winter on the Simpson Peninsula, Nunavut, and nearby islands to the northwest, and information on the sex and age class of a subsample of the occupants of 73 dens, were recorded from interviews with Inuit hunters at Pelly Bay, at intervals from 1937 to 1965 and 1968 to 1969. Hunting bears at winter dens, after locating them with the assistance of dogs, was legal during that period and was widely practiced throughout the Canadian Arctic. For embryos found in utero, mean litter size was 2.0, and two of the eight litters recorded from pregnant females contained three foetuses. Births appeared to occur from about December through early January. For cubs in dens, the mean litter size was 1.88. No litters of three cubs were recorded in winter dens or nearby after departure of the family back to the sea ice in spring. Females accompanied by yearling or two-year-old cubs, subadults, and adult males were also recorded in winter dens during periods of cold weather. The locations of a total of 191 snow dens, occupied during winter, were reported by hunters and marked on maps from memory. Of 180 dens for which the sex of the occupant was recorded, 148 contained females (alone or with an unspecified number of cubs) and 32 had lone males.
\end{abstract}

Key words: polar bear, Simpson Peninsula, Pelly Bay, snow dens, litter size

RÉSUMÉ. En se basant sur des entrevues menées à intervalles entre 1937 et 1965, et 1968 à 1969, avec des chasseurs inuits de Pelly Bay, on a consigné les emplacements hivernaux des tanières d'ours polaires dans la péninsule Simpson, au Nunavut, et dans les îles avoisinantes au nord-ouest, ainsi que l'information sur le sexe et le groupe d'âge d'un sous-échantillon des occupants de 73 tanières. Durant cette période, il était permis de chasser l'ours dans sa tanière hivernale, à l'aide de chiens pour la localiser, et cette activité se pratiquait à grande échelle dans tout l'Arctique canadien. Pour les embryons trouvés in utero, la taille moyenne de la portée était de 2,0, et deux des huit portées signalées provenant de femelles gravides contenaient trois fœtus. Les naissances semblaient se produire d'environ décembre jusqu' au début janvier. Pour les oursons dans les tanières, la taille moyenne de la portée était de 1,88. Aucune portée de trois oursons n'a été signalée dans les tanières hivernales ou dans les environs après le départ de la famille pour rejoindre la banquise au printemps. La présence de femelles accompagnées d'oursons d'un ou de deux ans, de jeunes adultes ou d'adultes mâles a également été notée dans les tanières hivernales durant des périodes de temps froid. L'emplacement d'un total de 191 tanières de neige, occupées durant l'hiver, a été rapporté par les chasseurs et marqué de mémoire sur les cartes. Sur les 180 tanières où le sexe des occupants a été rapporté, 148 contenaient des femelles (seules ou avec un nombre non précisé d'oursons) et 32 des mâles solitaires.

Mots clés: ours polaire, péninsule Simpson, Pelly Bay, tanières de neige, taille de la portée

Traduit pour la revue Arctic par Nésida Loyer.

\section{INTRODUCTION}

Throughout most of the Arctic, pregnant female polar bears (Ursus maritimus) dig maternity dens on land, in banks of consolidated, wind-drifted snow, in late autumn (Harington, 1968). Their altricial cubs are born in mid-winter, with their eyes closed, and weighing only about $0.6 \mathrm{~kg}$ (Derocher et al., 1992). Thus, the protection from wind and cold temperatures provided by the den is critical to the survival of cubs until they have been nursed for 3-4 months. Cubs weigh 10-12 kg when the females break out of their maternity dens in late March to early April (Ramsay and Stirling, 1988) and return to the sea ice to hunt seals.
To date, considerable field work has focused on identification of polar bear maternity denning areas in order to provide protection from disturbance or habitat destruction that might cause a female to depart before her cubs were large enough to survive, or to cease future denning in a particular area altogether. As a result, we now know that polar bear maternity denning is concentrated in areas such as Wrangell Island in Russia (Uspenski and Kistchinski, 1972), Kong Karl's Land in Svalbard (Larsen, 1985), and northeastern Manitoba near Churchill (Stirling et al., 1977). Such areas were termed "core areas" by Harington (1968). In most other areas, so far as is currently known, maternity denning tends to be more widely dispersed at relatively low

\footnotetext{
${ }^{1}$ Deceased.

${ }^{2}$ Canadian Wildlife Service, 5320122 St., Edmonton, Alberta T6H 3S5, Canada and Department of Biological Sciences, University of Alberta, Edmonton, Alberta T6G 2E9, Canada

${ }^{3}$ Corresponding author: ian.stirling@ec.gc.ca

(C) The Arctic Institute of North America
} 
densities (e.g., Stirling et al., 1984), although some localized areas still tend to have more dens on a regular basis than others (e.g., Schweinsburg et al., 1984, Amstrup and Gardner, 1994). Identification of these localized areas is important to the conservation of the polar bears that use them.

In contrast to the wealth of studies on the distribution of denning areas, relatively little information has been recorded on the biology of polar bears in their dens. This is true in part because occupied maternity dens are difficult to locate without the assistance of dogs (e.g., Harington, 1968) or radio collars (e.g., Amstrup and Gardner, 1994) but also because, in most jurisdictions, it is both illegal and dangerous to disturb bears in dens (see management reports in Derocher et al., 1998). In Canada, prior to 1968, it was both traditional and legal for Inuit to hunt polar bears in dens and this practice was fairly widespread, but with the exception of Harington (1968) and Van de Velde (1971), written records were not usually kept of their observations. After 1968, it became illegal to hunt or disturb bears in dens, but because this was a long-time traditional method of hunting, enforcement was phased in over one to two years in many areas to give hunters a chance to adapt. Since polar bears have not been hunted at dens in Canada for over 30 years, whatever data exist from earlier years on this critical phase in their life history are extremely valuable and unlikely to be collected again. In this paper, we report on a unique set of observations on the locations of polar bear winter dens and their occupants on the Simpson Peninsula and adjacent areas. These observations were collected over approximately 30 years, beginning in the late 1930s, during direct interviews with Inuit hunters in Pelly Bay, Nunavut.

\section{MATERIALS AND METHODS}

The study area for this project was the Simpson Peninsula (known to Pelly Bay Inuit as Saattok) and adjacent islands to the northwest as far as the Astronomical Society Islands (Fig. 1). This is the traditional winter polar bear hunting area of the Inuit of Pelly Bay, Nunavut.

One of us (Van de Velde) resided in Pelly Bay from 1937 through 1965 and again for several months in 1968 69 . From the beginning, he was keenly interested in polar bears, so that throughout his time in Pelly Bay, he interviewed hunters about observations of polar bears at all seasons. When possible, he recorded information soon after the hunters returned from a trip, but some information was also recorded from memory of past hunts when the events, but not necessarily the dates, could still be recalled. Van de Velde was fluent in Inuktitut and learned the words specific to bears of different sizes and age classes, which ensured correct understanding of what the hunters told him. Inuit hunters are particularly knowledgeable about the natural history of the species they hunt, in the areas and during the time periods they hunt them. Polar bears are also particularly important to the culture and economy of Inuit (e.g., Randa, 1986), and many hunters have accurate recall of the details of every individual bear they have killed. Thus, these records provided by the hunters from Pelly Bay, and documented by Van de Velde, represent a unique data set on polar bears in winter dens.

In 1952-55, and in 1968-69, when hunters returned from hunting polar bears in winter, including bears in dens, Van de Velde recorded the location of the den, the date it was opened, the air temperature at Pelly Bay on that day, the sex of most bears (except for cubs), and the number and age class (cub, subadult, adult) of all bears in a den. Of dependent cubs still with their mothers in dens during winter, those referred to as yearlings may range in age from about 11 to 14 months, and those referred to as two-year-olds, from 23 to 26 months. In some cases, the sex was not recorded. If the occupant of a den was a lone adult female, her reproductive tract was often, but not always, checked for the presence or absence of foetuses. Van de Velde recorded the number of cubs in a den, including older but still dependent cubs. In some cases of newborn cubs, he also noted whether the umbilical cord was still attached and the eyes were open, because those details provide a rough indication of the age of the cubs and hence the time of their birth.

This report is based on an analysis of existing written records, and only those from which the information was complete were included. Original records in French were translated into English and reviewed individually before inclusion in the results. Ian Stirling and Van de Velde exchanged several letters about details as the manuscript was being written, and interpretations were completed before Van de Velde's death. Unfortunately, the sample sizes included in this paper are smaller than those given in a preliminary article (Van de Velde, 1971), but some of the original data referred to there could not be located.

In separate interviews and discussions conducted over the time Van de Velde was in Pelly Bay, he asked individual hunters to indicate the location of every den at which they had killed bears over their hunting lifetimes on 1:250000 maps and, if remembered, the sex of each bear. In most cases, the exact year of the observation could not be recalled, so all dens were plotted on a single map (Fig. 1). Some of the hunts recorded may have preceded Van de Velde's arrival in Pelly Bay in 1937, but this is not known.

\section{RESULTS}

There were written records, with most details, on the occupants from November through February of 73 dens, 68 from $1952-55$ and 5 from 1968-69.

\section{Cubs in Dens}

The number of embryos in the uterine tracts of adult females in dens and the number of live cubs are summarized in Table 1. The mean litter size of eight litters of cubs 


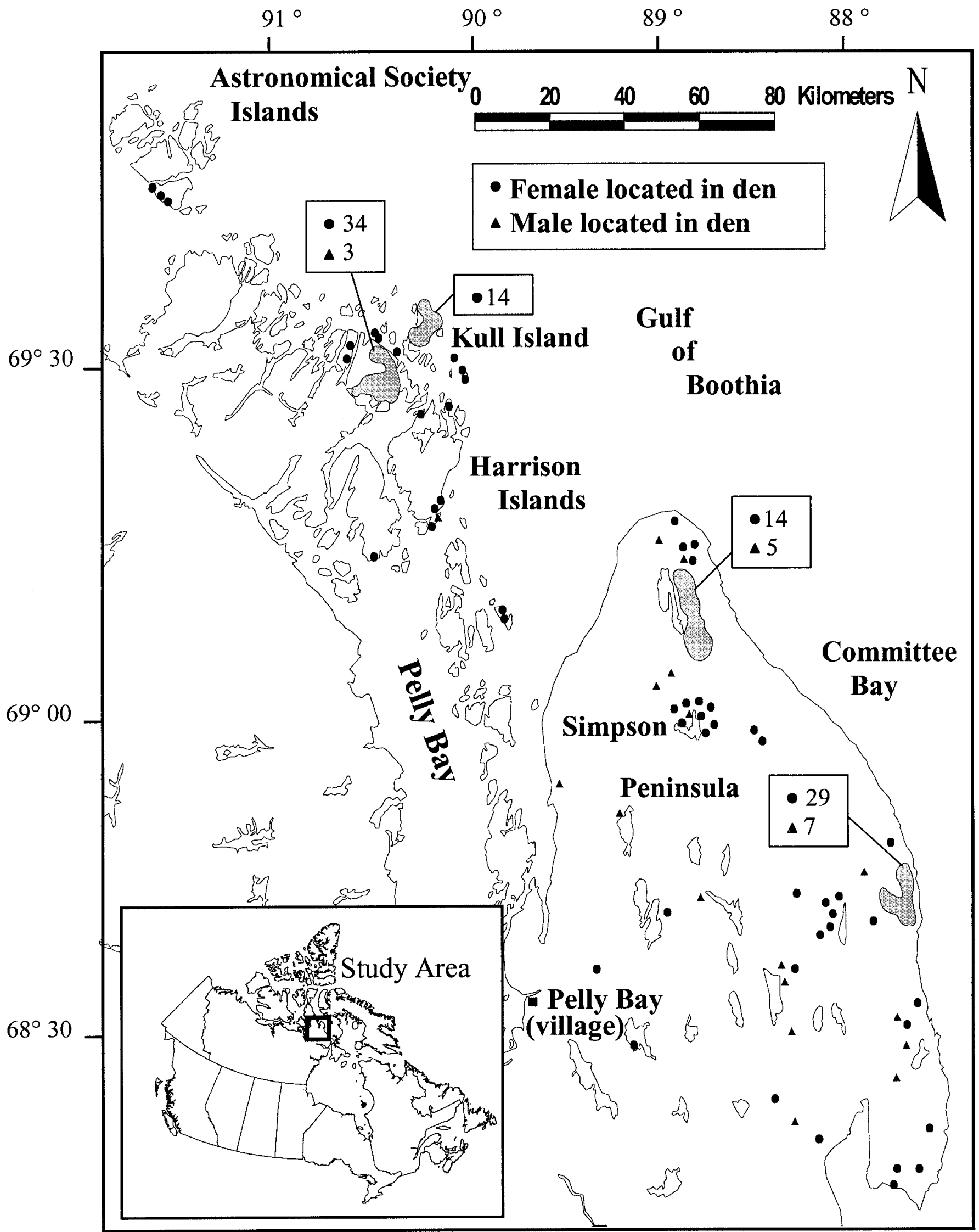

FIG. 1. Locations of 191 snow dens occupied by polar bears in winter on the Simpson Peninsula and adjacent islands, provided from living memory by Inuit hunters in Pelly Bay to Father Van de Velde, OMI, between 1952 and 1955 and in 1968-69. (The density of dens in grey shaded areas was too high to plot individual locations clearly at this scale, so the total number in each is given in the attached box.) 
in utero in November (7) and December (1) was $2.0 \pm 0.27$ (SE). Two of the eight litters had three foetuses.

The mean litter sizes were $1.6 \pm 0.25$ cubs in December, 2.0 \pm 0.14 cubs in January, and $1.8 \pm 0.12$ cubs in February, while the overall mean litter size of all litters in dens from December through February $(\mathrm{N}=25)$ was $1.88 \pm 0.08$ cubs (Table 1$)$.

No cubs were observed in dens in November, although seven females had embryos. Two additional adult females without cubs were found in dens in both November and December, but neither was examined internally to determine whether she was pregnant.

Of five females in dens in December, one had foetuses; two, observed on 9 and 18 December, had litters of cubs with closed eyes; and the other two had neither foetuses nor cubs. The cubs seen on 9 December had dry navels. Of 11 litters recorded in January, one litter had cubs with a wet umbilicus on 6 January, and two litters of cubs had their eyes closed on 1 and 10 January. Of the remaining eight litters, six had cubs with open eyes and two did not have this information recorded. Of 11 litters recorded in February, two had cubs with their eyes closed on 5 and 9 February. While there was no written comment on the eyes of the remaining nine litters, they were all thought to have been open.

\section{Adult Females Alone}

Eight more lone adult females were found in dens, seven in January and one in February. Of those, five were examined for embryos in January, but no foetuses were found. Neither of the remaining two found in January was accompanied by cubs, but one had nursed sometime previously and one had developed enlarged nipples as if preparing to nurse. (An experienced person can recognize that a female polar bear has nursed recently, or has swollen mammary glands and nipples in preparation for nursing.) Thus, the absence of cubs with the latter two females suggests they may have been stillborn or, for some other reason, were eaten. The air temperatures in Pelly Bay on the January days when females were found alone in their dens ranged from $-28^{\circ} \mathrm{C}$ to $-41^{\circ} \mathrm{C}$.

Adult Females with Older Dependent Cubs, Subadults, and Males in Dens

Five females accompanied by yearlings were found in dens: one in November, two in January, and two in February. The mean litter size was $1.20 \pm 0.20$. One female was noted as having abundant milk, one female was dry, and nothing was recorded about the other three. The temperatures at Pelly Bay on the days the two females with yearlings were reported in dens in January were $-32^{\circ} \mathrm{C}$ and $-52^{\circ} \mathrm{C}$. It was $-57^{\circ} \mathrm{C}$ when the two dens were found in February. Two females accompanied by two 2 -year-old cubs were found in dens: one in November and one in February. One adult male was found in a den in November and two in January, on days when the temperatures in Pelly Bay were $-25^{\circ} \mathrm{C}$ and $-41^{\circ} \mathrm{C}$, respectively.

\section{Distribution and Occupation of Winter Dens by Polar Bears}

The locations of 191 snow dens occupied during winter were recorded by hunters from memory on 1:250 000 scale maps (Fig. 1). Of these dens, 148 had females (alone or with an unspecified number of cubs), and 32 had lone males, while the sex was not reported for the occupants of 11 dens. The mean distances to the coast of dens occupied by male bears $(8.97 \pm 8.37 \mathrm{~km})$ and by female bears $(5.51$ $\pm 9.44 \mathrm{~km})$ were not significantly different $(\mathrm{t}=1.914, \mathrm{df}=$ $178, p=0.057)$

\section{DISCUSSION}

\section{Litter Sizes of Cubs in Dens}

Although the sample size analyzed here was small, the average litter size of eight pregnant females was 2.0, and two of the intrauterine litters had three cubs. Van de Velde (1971) reported a similar but slightly lower intrauterine mean litter size of $1.91(\mathrm{n}=36)$. Since no triplet litters were reported either in or out of dens in Van de Velde's records, it seems that a third cub in a litter is likely to die, either before birth or before leaving the den.

The mean size of 25 litters of cubs in maternity dens with their mothers in the Simpson Peninsula area between December and January was 1.88 , slightly higher than the mean of $1.80(n=56)$ reported by Van de Velde $(1971)$. These values are essentially the same, and they lie roughly in the middle of the range of mean litter sizes (1.50 to 2.27) recorded at the den site in spring from 10 different locations spread throughout the Arctic (Derocher, 1999). However, since the litter sizes reported here and by Van de Velde (1971) were all recorded a month or more before families would normally leave their dens in spring, it is likely that intra-den mortality would have resulted in smaller litter sizes by the time the families exited. Two of the lone adult females found in dens showed signs of having nursed or being prepared to nurse, suggesting that they had lost their cubs and had likely eaten them.

Van de Velde (1971) reported a mean litter size of 1.50 $(n=4)$ and no triplets among litters killed after leaving the den. Similarly, in a sample of 36 females with cubs in spring caught away from the den site in the Gulf of Boothia and areas farther west, Furnell and Schweinsburg (1984) saw no triplets and recorded a mean litter size of $1.64(\mathrm{n}=$ 36). From these data, we conclude that survival of triplet litters is rare in the study area (Fig. 1) and that mortality of cubs in the first few months after leaving their dens is in the range of $15 \%-25 \%$.

\section{Time of Birth}

Dates of birth of wild polar bears in maternity dens are almost unknown. From observations at the Leningrad Zoo (Kost'yan, 1954) and Utah's Hogle Zoo in Salt Lake City 
TABLE 1. Numbers of foetuses and cubs recorded with adult female polar bears killed in dens on the Simpson Peninsula, Nunavut, in 195255 and 1968-69.

\begin{tabular}{|c|c|c|c|c|c|c|c|}
\hline \multirow{3}{*}{$\begin{array}{c}\text { Years of Records } \\
1952-55 \text { \& 1968-69 }\end{array}$} & \multicolumn{7}{|c|}{ Number of Foetuses or Cubs with Female in Den } \\
\hline & \multicolumn{2}{|c|}{ November } & \multicolumn{2}{|c|}{ December } & \multirow{2}{*}{$\begin{array}{c}\text { January } \\
\text { cub }\end{array}$} & \multirow{2}{*}{$\begin{array}{l}\text { February } \\
\text { cub }\end{array}$} & \multirow{2}{*}{$\begin{array}{l}\text { Total (December-February) } \\
\text { cub }\end{array}$} \\
\hline & foetus & cub & foetus & $\mathrm{cub}$ & & & \\
\hline Number of litters & 7 & 0 & 1 & 3 & 11 & 11 & 25 \\
\hline Number of young & 14 & - & 2 & 5 & 22 & 20 & 47 \\
\hline Mean litter size & 2.0 & - & - & 1.6 & 2.0 & 1.8 & 1.88 \\
\hline SE & 0.28 & - & - & 0.25 & 0.14 & 0.12 & 0.08 \\
\hline
\end{tabular}

(D. Tomkinson, pers. comm. 2002), it appears that the umbilicus may disappear within a few hours (probably eaten) and the eyes open at about 30-31 days of age. From this anecdotal information, it is possible to approximate the parturition period for female polar bears in the study area. The absence of cubs in dens, but presence of foetuses in the females, in November suggests that few litters are born in that month. One litter of cubs on 9 December had dry navels, indicating they could have been born within a few days. The cub with a wet umbilicus on 6 January was likely born within the previous one or two days, and the two with their eyes closed in the first half of the month could have been born up to a month earlier (i.e., in midDecember). Cubs in two litters found around the first week of February had their eyes closed and so could also have been born up to a month earlier (in early January). Collectively, these observations suggest that polar bear cubs in the Simpson Peninsula area are probably born between early December and early January.

From analyses of serum progesterone levels and movement data from satellite radio collars, Derocher et al. (1992) estimated that polar bears in western Hudson Bay $\left(58^{\circ} \mathrm{N}\right)$ gave birth to their young from mid-November to mid-December. Messier et al. (1994) analyzed activity data from satellite collars on female polar bears in maternity dens in Viscount Melville Sound $\left(74^{\circ} \mathrm{N}\right)$ and suggested they gave birth about mid-December. The time of birth of cubs in the Simpson Peninsula area $\left(69^{\circ} \mathrm{N}\right)$ appears to be later than in western Hudson Bay and more similar to that reported farther north in Viscount Melville Sound. Harington (1968) reported a similar, if crude, gradient from the estimated birth dates of six cubs born between about $56^{\circ} \mathrm{N}$ in southern Hudson Bay and $80^{\circ} \mathrm{N}$ in Franz Josef Land, Russia. Using back calculations of growth rates from measurements of very young cubs, Lønø (1970) estimated that birth in Svalbard $\left(76^{\circ} \mathrm{N}\right)$ occurred from early January to early February. Collectively, these data suggest that cubs born at higher latitudes are born later than those at lower latitudes.

\section{Bears Other Than Females with Cubs in Dens}

It is common for Inuit hunters to report that bears other than females with cubs may use snow dens for briefer periods than parturient females to escape particularly cold or stormy weather during winter (Van de Velde, 1971).
Similarly, Uspenski and Chernyavski (1965), Harington (1968), and Lønø (1970) reported that male bears use temporary dens in cold weather or winter storms. After interpreting temperature data from satellite radio collars, Messier et al. (1994) reported that two females accompanied by yearling cubs had occupied dens for 102 and 150 days, respectively. Following Harington (1968), they termed this behavior "sheltering" rather than denning. Ferguson et al. (2000) reported that the mean length of "shelter" denning of 21 adult females with satellite radio collars during winter was 65 days (range 35-86 days).

In the detailed records from the Pelly Bay hunters, reported above, 33 females with either foetuses or cubs were recorded in dens. During the same period, five females accompanied by yearlings, eight lone adult females, two females with two-year-old cubs, and three adult males were recorded in snow dens in mid-winter. Temperatures at Pelly Bay were not noted for all the days on which these latter observations were made, but those that were recorded ranged between $-28^{\circ} \mathrm{C}$ and $-57^{\circ} \mathrm{C}$. In the living memory summary of where bears had been found in dens (Fig. 1), the sex was recorded for the occupants of 180 dens, of which $32(17.8 \%)$ were lone males. From these data, it is clear that the number of bears other than just pregnant females that use dens regularly during winter to conserve energy during cold weather is much larger than is generally apparent from the literature.

Ferguson et al. (2000) reviewed the use of "shelters" by a sample of 45 female polar bears with satellite radio collars. They concluded that bears at latitudes of about $70^{\circ}-75^{\circ} \mathrm{N}$ use shelters on land in late summer and fall while waiting for freeze-up, or in mid-winter to avoid periods of extreme cold. The median freeze-up date over the area they examined, 2 November, is much later than along the northern and eastern coasts of the Simpson Peninsula or the Harrison Islands, where consolidation between 1971 and 2000 was complete by the end of September (Canadian Ice Service, 2002). Thus, both the timing of freeze-up and the temperatures measured at Pelly Bay on the dates when bears were found in dens in this study suggest that the occupants were probably avoiding cold to conserve energy.

Derocher et al. (1990) demonstrated experimentally that polar bears appear able to alternate between a fasting and a feeding metabolism at any time of year, depending on food availability. Thus, during periods of cold weather 
in mid-winter, when seals are inaccessible because of open water or less accessible because of intense cold, it appears that polar bears of all ages and sexes conserve energy by a dual strategy of sheltering in temporary snow dens and lowering their metabolic rate to fasting levels.

\section{Distribution of Maternity Dens}

Van de Velde (1971) reported that dens made by pregnant females and bears of other age and sex classes tend to be found in the same areas year after year, although he did not name any such locations. However, cumulatively, the data in Figure 1 indicate where hunters found bears in dens in the study area in winter. Although some dens were fairly widely distributed at low density, there were also localized areas where greater numbers of dens were regularly found over the years, such as the northern end and middle of the eastern side of the Simpson Peninsula, Kull Island and the mainland peninsula to the southwest, and the Astronomical Society Islands (Fig. 1). Between 24 March and 4 April 1986, Gunn et al. (1991) conducted a denning survey by snow machine that included the locally known traditional denning areas in the Harrison Islands northwest of Pelly Bay. One den was found near Kull Island $\left(69^{\circ} 33^{\prime} \mathrm{N}\right.$; $90^{\circ} 19^{\prime} \mathrm{W}$ ) and 23 were located on the mainland peninsula immediately to the southwest, where one of the greatest densities of dens was also recorded from the historical data set $\left(69^{\circ} 30^{\prime} \mathrm{N} ; 90^{\circ} 30^{\prime} \mathrm{W}\right)$ (Fig. 1). Nine dens had been dug by single bears, of which one was an adult male, three were females without cubs, and the rest were younger bears. Two of the dens had been used by single bears for shorter periods and were only lightly iced on the inside. Two dens were still occupied during the survey, one by a female and cubs on 30 March and one by a lone female on 31 March. Although it is clear from the data in Figure 1 and Gunn et al. (1991) that some specific areas are more important than others for polar bear denning, it is not possible to predict the number or density of dens in a particular location on an annual basis.

In this study, we found that the average distances from the coastline of dens occupied by male and female polar bears were $8.97 \pm 1.48$ (SE) and $5.51 \pm 0.78 \mathrm{~km}$, respectively. No one else has reported comparable observations for male bears sheltering in dens, but Harington (1968) reported that of 113 maternity dens he recorded at four different locations in the Canadian Arctic, 69 (61\%) were within $8 \mathrm{~km}$ of the coast, though he did not give any numbers and some of the smaller islands surveyed are only a few kilometres across. In the area of Viscount Melville Sound in the Canadian High Arctic, Messier et al. (1994) reported the average distance of 25 maternity dens from a shoreline was $8.6 \pm 1.5(\mathrm{SE}) \mathrm{km}$. Taken together, these data suggest that in the treeless coastal areas of the Arctic, most female polar bears den within a few kilometres of the coastline. The distribution of dens in individual years likely varies with the distribution of suitable snowdrifts, distribution and densities of adult males in coastal areas, and an energetic preference for not traveling any farther than necessary in spring to return to hunting seals after fasting for four or more months.

\section{Concluding Comments by Stirling and Richardson}

In the field of reporting traditional knowledge, the data recorded by Van de Velde are of unusual quality because so much of the information he received was carefully written down at the time and reviewed with individual hunters to ensure accuracy while their memories were fresh. With hindsight, as this paper was being written, he regretted not seeking more specific information that hunters might have remembered about some of the dens they plotted on his map from memory. Even so, his records are sufficiently quantitative to provide unique insights into pregnancy rates, litter sizes of cubs prior to leaving the den, and winter denning in the region hunted by Inuit from Pelly Bay. It is no longer legal to hunt or harass polar bears in dens, so the collection of similar data in the future, anywhere in the Arctic, is unlikely. Although we have previously heard hunters comment that they sometimes see bears other than pregnant females in dens in winter, so far as we are aware, only Van de Velde's data give any quantitative insight into the extent and ecological importance of this phenomenon. His quantified documentation of observations of bears in dens in winter, in the areas of the northern and eastern coasts of the Simpson Peninsula and the Harrison Islands and adjacent areas of the mainland, makes it clear that these are important denning areas for the polar bears resident in the region, for both maternity and shelter denning. It is also clear that these areas have been important for many years; therefore, should large-scale land use activities ever be considered there, efforts should be made to minimize possible detrimental effects on polar bears in both maternity and shelter dens. Lastly, Van de Velde's careful recording allows credit for making these invaluable observations on polar bear biology and ecology to go to the people that made them: the Inuit hunters from Pelly Bay.

\section{ACKNOWLEDGEMENTS}

First and foremost, we wish to acknowledge and thank the Inuit polar bear hunters of Pelly Bay, Nunavut, for sharing their observations, insight, and friendship with Father Franz Van de Velde, OMI, through the 30 or so years he lived in Pelly Bay. By allowing a written record of their observations to be made at the time, the hunters facilitated the creation of a unique and valuable database on the biology of polar bears in their hunting area. Dr. F. Messier and two anonymous reviewers made important suggestions for the improvement of the manuscript. We thank Mr. Doug Tomkinson, Animal Care Supervisor, Utah's Hogle Zoo, Salt Lake City, for permission to use his unpublished observations on newborn polar bear cubs, and Ms. Anne Cardasilaris for translating Van de Velde's polar bear notes from French into English. Lastly, we thank 
the Canadian Wildlife Service and the Department of Biological Sciences, University of Alberta, Edmonton, for support during the writing of this paper.

\section{REFERENCES}

AMSTRUP, S.C., and GARDNER, C.L. 1994. Polar bear maternity denning in the Beaufort Sea. Journal of Wildlife Management 58:1-10.

CANADIAN ICE SERVICE. 2002. Sea ice climatic atlas: Northern Canadian waters, 1971-2000. Ottawa: Public Works and Government Services of Canada. 177 p.

DEROCHER, A.E. 1999. Latitudinal variation in litter size of polar bears: Ecology or methodology? Polar Biology 22:350-356.

DEROCHER, A.E., NELSON, R.A., STIRLING, I., and RAMSAY, M.A. 1990. Effects of fasting and feeding on serum urea and serum creatinine levels in polar bears. Marine Mammal Science 6:196-203.

DEROCHER, A.E., STIRLING, I., and ANDRIASHEK, D. 1992. Pregnancy rates and serum progesterone levels of polar bears in western Hudson Bay. Canadian Journal of Zoology 70: $561-566$.

DEROCHER, A.E., GARNER, G.W., LUNN, N.J., and WIIG, Ø., eds. 1998. Polar bears. Proceedings of the Twelfth Working Meeting of the IUCN/SSC Polar Bear Specialist Group, 3-7 February 1997, Oslo, Norway. Occasional Paper of the IUCN Species Survival Commission 19. 159 p.

FERGUSON, S.H., TAYLOR, M.K., ROSING-ASVID, A., BORN, E.W., and MESSIER, F. 2000. Relationships between denning of polar bears and conditions of sea ice. Journal of Mammalogy 81:1118-1127.

FURNELL, D.J., and SCHWEINSBURG, R.E. 1984. Population dynamics of central Canadian Arctic polar bears. Journal of Wildlife Management 48:722-728.

GUNN, A., GOO, A., ASHEVAK, J., JONES, L., and KAOMAYOK, D. 1991. Polar bear denning surveys in the Kitikmeot Region, 1977-86. Yellowknife: Northwest Territories Department of Renewable Resources. Manuscript Report 45. $31 \mathrm{p}$.

HARINGTON, C.R. 1968. Denning habits of the polar bear (Ursus maritimus Phipps). Canadian Wildlife Service Report Series No. 5.30 p.
HAWKES, E.W. 1916. The Labrador Eskimo. Memoir No. 14, Anthropological Series, Geological Survey, Department of Mines. Ottawa: Government Printing Bureau.

KOST'YAN, E.Ya. 1954. New data on polar bear reproduction. Zoologischeskiy Zhurnal (Moscow) 33:207-215. Canadian Wildlife Service Russian Translation 66. Ottawa: Department of Environment.

LARSEN, T. 1985. Polar bear denning and cub production in Svalbard. Journal of Wildlife Management 35:27-36.

LØNØ, Ø. 1970. The polar bear in the Svalbard area. Norsk Polarinstitutt Skrifter 29:1-103.

MESSIER, F., TAYLOR, M.K., and RAMSAY, M.A. 1994. Denning ecology of polar bears in the Canadian Arctic Archipelago. Journal of Mammalogy 75:420-430.

RAMSAY, M.A., and STIRLING, I. 1988. Reproductive biology and ecology of female polar bears (Ursus maritimus). Journal of Zoology (London) 214:601-634.

RANDA, V. 1986. L'ours polaire et les Inuit. Paris: Société d'Études Linguistiques et Anthropologiques de France.

SCHWEINSBURG, R.E., SPENCER, W., and WILLIAMS, D. 1984. Polar bear denning area at Gateshead Island, Northwest Territories. Arctic 37:169-171.

STIRLING, I., JONKEL, C., SMITH, P., ROBERTSON R., and CROSS, D. 1977. The ecology of the polar bear(Ursus maritimus) along the western coast of Hudson Bay. Canadian Wildlife Service Occasional Paper 33. 64 p.

STIRLING, I., CALVERT, W., and ANDRIASHEK, D. 1984. Polar bear ecology and environmental considerations in the Canadian High Arctic. In: Olson, R., Geddes, F., and Hastings, R., eds. Northern ecology and resource management. Edmonton: University of Alberta Press. 201-222.

VAN de VELDE, F. 1971. Bear stories. Eskimo (New Series) 1: $7-11$.

USPENSKII, S.M., and CHERNYAVSKI, F.B. 1965. Maternity home of polar bears. Priroda 4:81-86.

USPENSKII, S.M., and KISTCHINSKI, A.A. 1972. New data on the winter ecology of the polar bear (Ursus maritimus Phipps) on Wrangel Island. International Conference on Bear Research and Management 2:181-197. 